\title{
The Searchers: Aristoteles Revisited
}

\author{
Manuel Bernardo Cabral \\ Direção Regional da Cultura, Portugal \\ António Costa Valente \\ $\mathrm{CIAC}$, Universidade do Algarve, Portugal
}

\begin{abstract}
In the first half of the 20 $0^{\text {th }}$ Century, the "western" was a major genre in Hollywood filmography. Starting as a simple and almost childish type of entertainment easily attained by the audience, it evolved into a more sophisticated form of film communication and art, and become the preferred genre for some film directors like Howard Hawks and John Ford, among others. This evolution allowed the genre to become an important tool of analyses and criticism of American Culture, History, Myths and Society, especially during the time of the McCarthyism and the Red Scare, a time when progressive and more critical views on these subjects could not be openly dealt with. Among the authors who saw the "western" as this privileged means of expression, Ford definitely stands tall, and in his filmography, "The Searchers" occupies a front row seat. For all of the above, we intend to bring some light to this movie, analysing some aspects of its narrative from the perspective of the Aristotelian principles of dramatic construction.
\end{abstract}

Keywords: Western, Indians, Racism, Narrative.

\section{Introduction}

Shot in 1956 and starring John Wayne, "The Searchers" is one of the best known John Ford "westerns", a genre which Ford particularly cultivated. Produced in the last stretch of Ford's long film career, it has, together with "The Man who Shot Liberty Valance" and "Cheyenne Autumn", a particularly critical view on themes that have always been dear to him. From this trio of westerns, "The Searchers" and "Cheyenne Autumn" ${ }^{1}$ have a special significance, because Ford uses them to denounce racism in the way the North American society dealt with its Native People. This is a landmark in Ford's career. The way Ford had treated the Native Americans in his previous films granted him a reputation as a bigot racist among certain authors and scholars. "The Searchers" represents a small change in this treatment and seems to be a preparation for a fully fleshed apology to the Native Americans that comes in 1964 with "Cheyenne Autumn".

"The Searchers" narrates the story of Ethan Edwards, an uncompromisingly racist confederate officer, who returns home three years after the secession war. After his arrival an Indian attack destroys his brother's place, killing him, his wife, son and older daughter. Debbie, Ethan's youngest niece is kidnapped by the Indians launching him in a long search to find her. As the years pass his objective of bringing Debbie home changes. She's a grownup girl now and probably married to a
Comanche, which turns her in one of them at Ethan's eyes. So killing Debbie becomes his real objective, which Martin Pawley, his step-nephew and partner in the search will try to prevent. The film's storyline spared Debbie from having any off-springs from Scar and spared Ford the trouble to deal with the essence of racism: the horror of tainted blood. The film ends with Ethan accepting Debbie and taking her home. The death of Scar, the Comanche chief that massacred his family, captured Debbie and married her, deflates his hate and allows him to accept her back.

The theme of racism is not the only one in this movie. Assembled like an "epic", the film brings other themes to the viewer, intersecting and combining among themselves along the narrative to once more bring to the screen Ford's perspective on the American History. A perspective that we intend to analyse from a film criticism point of view, taking Aristoteles teachings in "Poetica" as our departing point and reference.

\section{Mimesis and Diegesis}

The notions of diegesis and mimesis and how they interplay in a movie are not exactly simple. For Aristoteles, in a simplified manner diegesis would be what is told, what is narrated and mimesis what is shown, what is acted, as acting is indeed imitation. Comedy and tragedy would essentially use mimesis, while an epic would mostly be diegetic. In this scheme of things, in our days, written works meant to be read, like novels or romances, would be diegesis, while plays and movies would be mimesis. However things are not that simple. Printed work like novels and romances have characters to whom character traits of real humans are attributed, and dialogues that should be adequate to the character. So, one wonders if the reader, when picturing a character in his mind and echoing his or her words in his brain is not actually doing some kind of mimesis, as he is actually being driven by the author to build an imitation of a human being in his mind. This may seem taking things a bit too far, but it is a legitimate reasoning. But even if we decide to keep things closer to our subject, the movies, this straight line that separates diegesis from mimesis is more complex than it seems. Any narrative film includes the narrated facts, characters that experience these facts, narration techniques and forms used to tell the story, and a narrator responsible for the narration. This implies that everything in the film is part of the narrative, including the characters, their actions and their dialogues. In other words, everything in the film is diegesis, including the mimesis, the part that the actors act and speak their lines. This difficulty with the separation of mimesis and diegesis has been 
addressed by Gadreault which came up with a notion of "mimetic diegesis", a definition that acknowledges that the mimesis, the imitation of men (inferior men in the comedy, superior men in the tragedy and epic according to Aristoteles), although distinct as a narrative technique from a narrator's speech, is part of the narration. This inclusion means that we accept the writer as the main narrator, one that contains and manipulates all the other possible narrators, external or internal, as well as all characters, and expresses himself through them all. To simplify it, I would say that diegesis in a broader sense ca $n$ be understood as "mimetic diegesis", as Gadreault put it, containing everything that pertains to the narrative, while diegesis in a restricted sense refers solely to the narrated parts of the narrative, and mimesis to the acted parts. This is actually the meaning I will be attributing to these terms, when using them in this paper.

In our usual genre classification we can say that "The Searchers" is a "western". The time and space where the narrative unfolds, the narrative codes and the symbols it uses all point to that. But "The Searchers" is not just a simple western. We can also classify it as an "epic western". Although film narrative has derived mostly from a blend of the classical tragedy and the epic poem, certain types of films who conform closer to the rules of the classical epic poems are classified as "epics", and "The Searchers" is certainly an "epic". Its two hour length, although not excessive (remember Titanic) is above the hour and an half average of most movies, and a longer duration is one of the distinctions for Aristoteles between tragedy and epic. The time span of the action is another difference and while the tragedy should limit itself to a period of the sun (one day), the epic poem had no limits. In this film we have an action that spans over a period of five years, an epic time span. Its narrative uses mimesis as the tragedy, but also moments of diegesis, as parts of the story are actually narrated, like in the classical epics. And finally, the all story structure resembles an epic poem like Virgil's "Aeneid" or Homer's "Odyssey".

Like most of the narrative films "The Searchers" plays heavily on the mimesis. The writer/narrator yields his/her diegetic role to the mimetic function of the actor, actually relying on him or her as a narrative vehicle. Playing his role as a racist ex-confederate officer, John Wayne is fulfilling a mimetic function. Ethan Edwards is an imitation of a possible human being with certain personality traits, as Ward Bond's reverend/captain Clayton, or any other characters of the story. Their actions and their dialogues are tools for the writer/narrator to tell the story. And he tells us the story by actually making it happen in front of our eyes through the use of mimesis. But "epics" have certain codes, and one of them is the use of narrators to tell part or parts of the story. The use of this device helps to shorten certain passages, too long or not important enough to be re-enacted, and is a time lapse tool that helps to forward the action, an important function in a type of narrative that allows for unlimited time spans, that is used in this film in the letter reading sequence. "The Searchers" follows this pattern and the diegesis of a narrator intertwines with the mimesis of action and dialogue in a well-orchestrated and smooth interplay. Always using some of the characters as internal narrators, the film explores different levels of narration in an almost dialectical way. When Ethan comes out of the canyon where he buried Lucy we don't know what happened in there, but his expression and emotions (mimesis) do tell us that something happened. We will know Lucy is dead later on when they find the Indian camp and he finally tells them. At this moment he plays a double role, because he stays in character (mimesis), and it is as a character that he narrates (diegesis) how he found and buried Lucy. Another instance where a character takes the role of a narrator is when Lori reads Martin Pawley's letter. Also staying in character, she becomes the narrator. Her words (diegesis) prompt a return to the action (mimesis) in a flashback interrupted once by her reading. The most interesting here is that there are actually two narrators in this letter reading sequence. Lori who actually reads the letter and is an active narrator and Martin Poly, who wrote it and is some sort of a passive narrator. In a very subtle way, Ford makes a point of bringing this double narrator situation to the attention of the viewer and in the conclusion of the reading, Martin's voice overlaps for a moment on Lori's.

Film is an audio-visual medium and naturally the narrative devices are not restricted to the soundtrack. Image is a major narrative tool, a diegetic element which can be used to deliver information or actually to tell a parallel story, playing a subtext role that can also be found in the audio as well. Like most Ford's movies, "The Searchers" can be peeled off like an onion, where we can continuously find layers of meaning under the previous layer. In this film in particular he uses the camera and the mise-en-scéne, particularly the setting, to take us beyond the theme of racism and into the theme of civilization, one of his favourites and an almost sure presence in his "westerns". Here, the majesty of the landscape is shot in a way that always dwarfs the civilized men's creations. The houses and ranches are tiny islands threatened by the mightiness of the nature that surrounds them, in a dialectical game of wilderness versus civilization, where the door frame plays an important role as the element that separates nature from the humanized environment of the human shelters, the link between both worlds. The movie starts with a door opening to the landscape and finishes with a door closing over the landscape. In between these two doors Ford plays with the door motif over and over again, changing its form to a tepee entrance and to a cave entrance, as if going on some retrospective trip on the History of humanity, starting with a house, a sedentary homestead symbol of civilization, then a tepee, a shelter from the nomadic period of our history and going all the way back to the cave, the primitive shelter of our earlier ancestors. It's like a journey into history, but also a symbolic attribute of the characters. As he does in other movies, Ford plays here with the double meaning of the word frame which can also mean entrapment. Scar is framed by his tepee entrance when Martin kills him, because 
he is actually framed by his condition as an Indian, a man from a threatened nomadic culture. Ethan is framed by the house door, outside in the wilderness where his wandering personality belongs, or by the cave entrance in two sequences where he intended to kill Debbie, therefore allowing to come to surface his most primitive nature, appropriately symbolised by the cave framing. The repressed love of Ethan and his sister-in-law Martha is also witnessed always through door frames, as they are framed by their impossible love. But the door frame is not the only diegetic use of the symbolism of the image as a narrative device in this movie. Colour also plays an important diegetic role in the movie. The colour red, symbol of power and sexuality in our western culture is a recurrent element, underlining the sexual tensions and codes in the story. Aaron, Martha's husband wears a red shirt when Ethan arrives. But in the next day, Ethan, the repressed contender for Martha's love, wears a jacket of a brighter red than Aaron's shirt, and it is in this same red jacket that he wraps up Lucy's naked body, raped and killed by the Indians. Mrs. Pawley, Martin's Indian wife also wears red, and is unknowingly acquired by Martin when he buys a red blanket, that symbolises her hand, and everything that comes attached to it. Carmen, the sensual Mexican dancer also wears a red skirt, and in Martin's bath scene full of sexual innuendo with the presence of Lori, his underwear is red, just like the one that Lori brings to replace his ragged one. And naturally the grown up Debbie also dresses in red, while the covers of her matrimonial bed in the tepee are even of a stronger red, as if to confirm to the viewer and to Ethan that his strongest fears that she would be sexually touched by an Indian came true.

\section{The Structure as the Main Frame for the Narrative}

In his "Poetica" Aristoteles wrote that a tragedy should last long enough to allow a change from unhappiness to happiness and that it should have beginning middle and end. This is a clear call for action unity and the recognition that to keep the public's attention the play must have a certain extension and order, be complete and believable. Verisimilitude is therefore more important than reality and must be sustained by a sequential causality of the action. All of this should be wrapped in a structure that is organized in several parts: a "prologue", several "episodes" and an "exodus". Between each of these parts comes in the "chorus" that through music or dance comments on the action, expressing the fears and hopes raised by the narrative. The initial intervention of the "chorus" between the "prologue" and the first episode is called "párodo" and the following ones "estásimos". The practical result of these notions is the classical three act structure, still used today in cinema and perfected by Syd Field, Linda Seger and others. ${ }^{2}$ The way this structure works has been synthetized by George B. Cohan, an actor from the silent movies, who said that "first you put a character on a tree, second you throw rocks at him/her, and third you bring him/her down.
If he's alive is a comedy, if he's dead is a tragedy." (Clascà 1999, 129) This simplified way of describing a film is still valid today, as drama is precisely about facing difficulties and overcoming them or being overpowered by them. The three act structure however is no longer alone, and some authors say that the double length of the middle act makes it actually two acts, so what we have is actually a four act structure, while in the TV telefilm, a seven act structure is used. In "The Searchers" we can identify a classical three act structure, naturally with the double second act, but integrated in these three acts we can also discover seven parts, that could stand for seven acts if we would want to break down this film in a seven act telefilm structure.

\section{THE SEARCHERS: STRUCTURE}

\section{ACT I}

\section{INTRODUCTION OF THE CHARACTERS AND SET UP}

- Ethan Edwards arrives at his brother's home three years after the civil war.

- Ethan and Martha - a repressed love.

- Reverend/Captain Clayton and his men arrive.

- Ethan leaves with the Posse in pursuit of the Comanche.

- The Indians attack the Edward's ranch.

- The funerals.

\section{ACT II}

\section{THE BEGINNING OF THE SEARCH}

- Captain Clayton leads the Rangers in pursuit of the Indians.

- The "posse" is attacked by the Indians.

- After the attack is repealed, Ethan, Martin Poly and Brad

- Jorgensen continue the pursuit alone.

- Ethan discovers Lucy dead and buries her.

- Brads goes on a raging attack to the Indian camp and is killed.

- The snow forces Ethan and Martin to interrupt the search.

\section{INTERMEZZO}

- Ethan and Martin arrive at the Jorgensen's home.

- A letter from a bar owner named Jeremy Futherman puts them back on the trail.

- At the bar Futherman tells them that the chief who has Debbie is called Scar.

- Ethan kills Futherman when he attacks their camp to rob them.

- Charlie McCrory brings a letter from Martin to Lori.

\section{MID-POINT}

\section{MARTIN'S LETTER (Flashback)}

- Lori reads Martin's letter.

- Martin gets an Indian wife by mistake.

- Mrs. Poly is mistreated by her husband. 
- Lori interrupts the reading, jealous with Martin's marriage, but she continues prompted by her parents.

- Mrs. Poly leaves her husband.

- Ethan tries to slaughter a buffalo herd to deprive the Indians from food and is interrupted by the army's arrival.

- They follow the soldiers to an Indian camp raided by the army and find Mrs. Poly among the dead.

- At the Army Fort they look in vain for Debbie among the white women recaptured from the Indians.

- Lori finishes reading the letter.

\section{MEETING SCAR}

- They meet Moses who introduces them to Emilio

Fernandez Figueroa, who takes them to Scar.

- They talk to Scar in his tent and see Debbie, who is now one of his wives.

- After they leave the Indian camp Debbie comes to warn them that they're in danger. Ethan tries to kill her and is stopped, first by Martin and then by an Indian attack. Ethan is wounded

- They take refuge in a cave where they repel the attack.

- Ethan writes his will nominating Martin as his heir, refusing to consider Debbie as his kin.

\section{ACT III}

\section{THE WEDDING PARTY}

- At the Jorgensen's there's a wedding party for Lori and Charlie McCrory.

- Ethan and Martin crash in the party.

- Martin fights with Charlie because of Lori.

- The wedding is called off.

- Captain Clayton wants to detain Ethan and Martin

for questioning about Futherman's death.

- Lieutenant Greenwood brings Moses in with news from Scar's new hideout.

- Ethan, Martin, Captain Clayton and the Rangers leave after Scar. Lori tries in vain to make Martin stay this time.

\section{BRINGING DEBBIE HOME}

- They prepare to attack the Indian camp.

- Martin infiltrates in the Indian camp.

- The cavalry arrives.

- Martin finds Debbie and kills Scar.

- The Rangers and the cavalry charge.

- Ethan scalps Scar.

- Ethan runs after Debbie, catches her and holds her.

- Ethan brings Debbie to the Jorgensen's home.

- Ethan leaves alone.

Whether we decide to see three, four, or seven acts in this structure, the important is that the movie has a well-defined beginning, where the events point into a certain direction and challenge our characters to pursue a certain objective. In this movie finding the girls, at first, and after discovering Lucy's body, finding Debbie is the objective. After the setup of the situation in Act I, the acceptance of the challenge imposed by this situation on the main character spins the action into Act II. In the first half of Act II the obstacles to their objective pile up. They search for Debbie without a direction, not knowing who has her. In the mid-point their search becomes more focused, as they have learned from Futherman the name of the tribe and the chief who has Debbie. Now their quest is to find Scar, because finding him will lead to Debbie. They succeed in finding her, but Ethan's character fault makes them loose her. That is the end of Act II, and the Act III begins at a desperation point, because they have no clue again of Debbie's whereabouts. This moment is seized by the writer/narrator to tie up Martin and Lori's love story subplot, in what it is also one of the best moments of comic relief in the film. After that the Army comes in impersonated by Lieutenant Greenwood, bringing Moses, a character who knows where Scar and Debbie are. Moses' role is some sort of "god ex machine" from the classical Greek theatre, being the key to Scar's whereabouts twice in the narrative. Naturally Moses' role is believable and well justified by the plot, but nevertheless he seems to have that function, as he is always the one who delivers the solution for Debbie's whereabouts. The film ends with Scar's death and Ethan's acceptance of Debbie.

Returning to Aristoteles, we can also identify in "The Searchers" a "prologue", starting from the beginning of the movie, until Ethan leaves with Reverend/Captain Clayton and his "posse". Many "episodes" follow through the movie, until the "exodus", when Ethan brings Debbie to the Jorgensen's home and leaves alone, at the end. Between some of these episodes there is a "chorus" that no longer sings and whose functions are usually performed by some secondary characters like Mr. and Mrs Jorgensen. But although the "chorus" does not actually sings in movies today, except in the musicals of course, "The Searchers", although not being a musical, has two instances where the chorus actually sings: the funeral and the wedding. As a humoristic note, Ford uses the same music for both occasions.

Being an "epic" "The Searchers" storyline is built as a journey, a quest, just like "The Odyssey" and "The Aeneid". But while in these classical works the journey is from one point to another, as Ulysses' goal is to return from Troy to his beloved island of Ithaca and Eneas is to find a good place to settle after the destruction of Troy, "The Searchers" has a circular narrative. The objective of the journey is not to go from one place to another, but to find Debbie. Therefore the journey, and the movie, are bound to end at home, where it started, with the Jorgensen's ranch becoming the symbol of home after the destruction of the Edward's ranch. But this circularity is not only present in the macro structure of the film, dictating a return to the departing point at the end of the movie. The narrative itself is built in smaller circles. Departing with the "posse" from the Jorgensen ranch after the funeral, at the beginning of part 2, Ethan and Martin will return there in the beginning of part 3 , where they receive the clue that will put them back on track in the form of Futherman's letter. They will return again to the Jorgensen's in the form of Martin's letter at the beginning of part 4 , and again in 
person for the wedding on part 6 , where once more they receive information that puts them back on track. The Jorgensen ranch is an attraction pole to which they always return and where they always receive the information to continue their quest. The ranch is also the source for the main subplot (Martin and Lori) and a mark against which the viewer can establish and measure the epic time span of the narrative.

\section{The Characters}

Without well-built characters, even the perfect structure and the most brilliant plot may fail. That is why the creation of the characters is one of the most important jobs for the screen writer. To watch a movie is indeed to enter a world of characters that like us have feelings, problems, ambitions, etc. However, the film character is not exactly like a real person. The human being is too complex to be captured and explained in a two hour span or less that the average movie lasts. That is why the writer resorts to illusion to build his characters. What he creates are actually simplified people, whose complexity will depend on the job they will perform on the story, but that will never reach the complexity of a real human being. Yet, these characters need to be believable, they need to give us the impression they could be ourselves, our next door neighbour or any other person we know, otherwise the all story will look phony, and will crumble. These ideas are actually rooted in Aristoteles, for whom characters should look real, be constant and be built in a verisimilar way, thus rejecting the irrational. However, he allowed for different depths in this construction, depending on the kind of play. To convey drama in a tragedy or an epic, more complex characters that could reveal contradictory traits of personality that would spark internal conflict are more appropriate. $\mathrm{He}$ called them round characters, and their greater depth brings them closer to real human beings, making them more believable. They also have room for character change along the play, improving or worsening as the story unfolds, and describing what is called today "the character arch". This internal trip can be very important for the plot, as it can be simultaneously cause and effect of plot advancement. On the other end, he also made room for shallower characters, the flat characters that are mostly based on stereotypes, built using a narrower number of traits of the human personality, or even reducing it to one trait only. These characters, recommended for comedy, were typified by Teofrasto de Eresia that classified them according to their predominant trait, and became the model for the typical characters of the roman comedy.

Today we say that character is action. This is not new, as it was already true for Aristoteles. For him a character reveals himself by what he/she does and what he/she says. We cannot know a character except for his actions and speech. They are the vehicle that brings the inner self of the character to the public, revealing his/her strengths, weaknesses, values, interests and life objectives. In "The Searchers", the protagonist Ethan Edwards is a confederate officer that three years after the war still hangs to his uniform and sabre. That immediately establishes the racist nature of his character, confirmed by his reaction to Martin Pawley, who has Indian blood. A though, abrupt, but still likable man, Ethan is also a loner, and to a certain extent anti-social. Bordering between civilized and savage, his ability to survive in the nature makes him almost as much part of it as the Indians he hates so much. Like the Indians he is part of the landscape, a force of the nature. It is not by chance that he comes from the landscape in the beginning of the movie, and leaves to the landscape at the end, as it is not by chance that the Indians are pictured as part of the scenery, blending with it. But the film character does not exist alone. He or she moves in a fictional world with other characters, and his personality is often defined by the way he/she relates to these other characters. Ethan's character is mainly defined by the way he relates to the Indians. In this film the Indians are never personalized, except for Mrs. Pawley and Scar who are portrayed in the best tradition of the Hollywood stereotype for the North American Indian. They speak a broken English with verbs in the infinitive, mixed with strange words and big gestures. Mrs. Pawley is used as a comic relief in the film and ridiculed, while Scar has a stone face, and is portrayed as a savage. But in spite of this unfavourable treatment Scar's character is very important. He is a mirror image of Ethan, and their characters are the vehicle for Ford's statement on race relations between natives and white people in the film. Scar hates all the white people as much as Ethan hates the Indians. Racism is the driving force for both characters. But Scar's racism is different from Ethan's. While Ethan's racism steams from a cultural value in his own society, Scar's is derived from the way the white men treated the Indians. So, the white men's culture is actually responsible for the racist element in both races. Naturally, Ethan's character is richer than Scar's, who is pretty much a flat character. While Scar is the antagonist, Ethan is the protagonist of the movie. His racism is basic and primitive, uncivilized. It comes from the gut and makes him act in an absolutely insane manner turning him in a destructive force, like when he tries to slaughter a buffalo herd to deprive the Indians from food, or keeps shooting at them when they are already retreating at the river, or tries to kill Debbie. This contrasts with his otherwise civilized, polite and controlled character, allowing Ford to play on him a dialectical game of wilderness versus civilization. But these contrasts also give him depth, making him a round character, able of love and hate, and of contradictory feelings and actions. It is this roundness that allows him to change and to accept Debbie back, although the source for this change may never be fully explored in the movie.

Martin Pawley is Ethan's sidekick. But he is more than a conventional sidekick as he opposes Ethan sometimes, and although he helps Ethan to find Debbie, his goals are different. Martin wants to bring Debbie home no matter what, while Ethan wants to kill her if she is "tainted". Nevertheless Martin is the second most important character in this film, and the 
centre of the most important subplot, his love story with Lori. He is also an essential tool for Ethan to reveal his character, as most of Ethan's dialogues, essential to reveal character and advance plot, happen with Martin. Their opposite personalities help to create tension and therefore drama. But he doesn't have Ethan's depth and contradictions. He's above all a good character, only able to love. He loved Aaron and Aunt Martha, and he loves Lori and Debbie. His only dilemma his how to conciliate these two loves, as going after Debbie puts in jeopardy his love for Lori. But he chooses Debbie, although hopping not to lose Lori, as he knows he could not live his love story with her if that meant to have Debbie killed by Ethan. This dilemma, and the integrity he reveals in the actions he takes dealing with it, makes Martin a round character, the only one besides Ethan, although not as deep and as complex as him.

Lori Jorgensen is a young woman in love with Martin that aspires to be married. Her only conflict is between her love for Martin and her desire to get married before she turns into an old maid. Aside from her role as part of the chorus, this is her only dimension, making her a pretty flat character.

Moses Harper character is a very interesting one. $\mathrm{He}$ is a wanderer without a home, and as such he is identified with the Indians, whose dances he actually imitates in one scene. He also was baptized as an adult, which adding to the other facts reveal his "savage" nature. But he aspires to civilization. Using the motif of the rocking chair as a metaphor for the concept of home and civilized world, which in this film are almost synonymous, Ford shows how Moses wants to belong to this civilized world. He wants "a roof over his head and a rocking chair by the fire" as he tells Martin and Ethan in the fifth part of the film, a desire he had already expressed by actually siting on it at the Edward's house in the beginning of the movie. The rocking chair motif is not actually restricted to Moses, as other characters will sit on it, like Charlie McCrory. But Moses is the central character used by Ford to play this motif. He is also used by Ford to advance the action playing a "god ex-machine" role as we discussed above.

Charlie McCrory also sits on the rocking chair, portraying an idiot that represents the ridiculous side of civilized society. $\mathrm{He}$ is also the antagonist in the subplot of Martin and Lori's love story. He plays a fist fighting scene with Martin, a must in most Ford's movies, always used as a moment of relief, or even of comic relief as it is the case in here. His character is flat, only characterized by his idiocy.

Captain/Reverend Samuel Clayton is the Chorus headmaster, both as the rangers' captain and as the reverend. Clayton, the rangers, the neighbours, Mr. and Mrs. Jorgensen, all play the role of the Chorus. Charlie McCrory and Lori, although having other roles, also integrate the chorus, like when McCrory is integrated in the "posse", or when Lori reads Martin's letter, thus commenting and forwarding the action. They are all flat characters, although Captain/ Reverend Clayton may stand among them. The simple fact that he is two things, a captain and a reverend, and the way he "commutes" from one persona to another gives him a depth that the other characters do not have. Interesting to notice that this chorus actually sings twice, as pointed above, in spite of this movie not being a musical.

Martha Edwards is a very flat character, an icon that stands only as Ethan's impossible love interest. Her actions show that she nourishes the same feelings towards Ethan, as when through a door frame she tenderly takes care of Ethan's coat. She is also a strong woman, as we learn from Aaron's words, when he says that she "won't let a man quit". But these are the only two dimensions we know from her, and her importance in the story is mainly attached to Ethan's character.

Aaron Edwards also disappears too soon from the story to be fully developed, remaining another flat character. But we learn from his actions that he is a good man, a loving father and a courageous fighter, as the "posse" finds the dead Indians he shot, when they are in their pursuit. The way he deals with the unspoken love of Martha and Ethan also suggests a deepness of character that is not developed because of his character's early disappearance.

Debbie's character is very flat of course, both as a child and as a grown up. Her appearance is very restricted and therefore there is not much room for character development. When they finally find her she asks to be left alone, saying that the Indians are now her people, because she knows that after being married to an Indian she will not be accepted back in her society. She feels she's now "tainted" at the eyes of the white world. Although a child when she was kidnaped, she could apprehend that much. And so can the viewer, as even though none of the white characters shares Ethan's hate towards the natives and many of them look favourably on them, they all have a strongly ethnocentric position. They all share the same horror towards the idea of miscegenation. The idea that Debbie would be married to an Indian provoked different reactions but none of them favourable. Even the most liberal characters that favour a pacific coexistence of the two races do not accept the possibility of miscegenation. Mrs. Jorgensen one of the most sensible characters sees no point in continuing the search as Debbie is now grown up and "one of them". As for Debbie, there was certainly a lot of room to build a character in depth. How she dealt with the fact of marrying the man who killed her family, how she felt as an Indian, how she regarded the white men's way of treating the Indians, how she felt about Scar's death and returning home. All of this would certainly provoke a lot of contradictory and mixed feelings in any human being. But Ford, and the writer, decide to only hint at that, slightly scratching the surface of what this character could be. The reason is not difficult to guess. Shot in 1956, during the red scare period and with the McCarthy years still echoing, Ford certainly could not have taken his statements on racism and race relations any further than he did. He would have to wait for 1964 , in the context of the civil rights movement, to be able to further his criticism with "Cheyenne Autumn". But 
in 1956 he had to restrict himself, and bringing more depth to Debbie's character would force him to go beyond what was possible at the time.

Lieutenant Greenwood is another flat character, and a major source for comic relief in the story. Totally unexperienced as his name indicates, he represents the army, that he portraits as absolutely incapable. The interplay between Greenwood and Clayton is absolutely great, and an excuse for Ford to amuse his audience using an institution that he mostly revered in his previous movies. Another instance where Ford's criticism surfaces in this film.

Emilio Fernandez Figueroa is another very flat character. He does not exist beyond the stereotype of the Mexican type. He comes in only as a functional character, and this stereotyping is important because it helps to mask his merely functional role.

Character is revealed by action and dialogue as we stated above. But the action can be stressed up once more in here. The character's backstory is essential to make the character believable for his/her action. They have to be adequate to perform what the action asks them to do. Would Ethan be an eastern music teacher, the believability of his actions would be in jeopardy. His backstory as a soldier, and all his toughness are important for the verosimility of the story, as a weaker character would not be believable undertaking the task of facing Scar and rescuing Debbie. But believability also depends on the actor's performance. Ethan Edwards defines his character by his actions, but also by the mimesis of Wayne showing his rage against the Indians, the hate on his face after he scalps Scar and when he attempts to kill Debbie, his gentle attitude to Martha and to his nephew and nieces at the beginning, or his humorous approach to the wedding situation and to Lieutenant Greenwood. The believability of the character depends not only from his construction and the adequacy of his actions and dialogue, but also from the actor's interpretation. The mimesis is written by the writer, but carried out by the actor.

As a final note on the characters, we can say that Ethan's character stands high above all the others. Not even Martin Poly is round enough to come closer to him. However, this distance that could have unbalanced the movie is not felt. A carefully orchestrated choreography that masterfully plays the ensemble of the other characters, whether they are individualized or integrated as part of the Chorus, overcomes this distance and makes "The Searchers" one of the richest films in the use of the characters to deliver their mimetic function on the narrative. The film may have too much of Ethan Edwards, but the viewer hardly notices that.

\section{Plot Organization}

A script must be weaved like a tapestry, where all elements are interconnected in a way that they cannot be isolated, or the all tapestry will be destroyed. All scenes must be connected to the prior and to the next one, in a causality chain that will make the story evolve for worse or for better, and that cannot be broken. This continuous flow of the narrative must be contained in the parts of the narrative structure, and imply a notion of beginning middle and end for each action or episode with the ending of one scene originating the beginning of the next. This chain reaction must correspond to a linear time flow as a rule of thumb, although allowing for exceptions, like when the flashback is used. However, even the flashback must be motivated by the previous scene and must respond to a need to advance or clarify the action.

The dialectical organization of the script, with each scene answering to the previous one, uses three main dramatic devices like the setback, the discovery and the recognition. The setback is a reverse situation where things get worse for our characters, therefore creating one more obstacle for them to overcome. The discovery implies new information that may advance the action, reverse it, or spin it into a different direction, as it happens in the Plot Points of the movies. And the recognition scene is when a character discovers an identity.

Finally, a script must comply with the basic structure of the classical tragedy, respecting the unity of time, space and action, or will risk losing the public's interest. All these principles, derived from Aristoteles in his "Poetica" can be observed in "The Searchers". Not only its screenwriter Frank S. Nugent seems to have kept them in mind, but also Ford played with them quite well, as expected. Structured as a journey, as already pointed above, the film does not follow the conventional journey construction, as for example "Stagecoach", where the trip from Tonto to Lordsburg defines the objective quite well and facilitates the unity of the film. Here, the wandering nature of the journey could easily destroy the unity of space, time and action. However, keeping the Jorgensen ranch as a reference to which the main characters always return, and where they are fed the necessary information to continue their journey, keeps this unity intact, without breaking the chain of events that keeps the story moving forward.

A scene that is important to stress out is the scene where Martin kills Scar, not only because it is rich in image subtext, but also because it is a great example of how to build "suspense" using the elements discussed in here. Martin jumps from a cliff to the Indian camp and finds Debbie at Scar's tepee. Scar shows up and we have the scene's resolution with Martin killing him. But there are a few things in here worth pointing out. First, the fact that the viewer sees Scar before Martin does. After the audience sees him, Debbie sees him too, and only then Martin becomes aware of his presence. This technique of sharing information with the audience before the character is aware of it creates "suspense", especially when it is in a situation of danger like this one. Another interesting thing to point in here is that Scar dies framed by his tepee entrance, an attribute of his character, and although it is his tepee he is the one who is outside in the natural environment and not in the humanized environment of the human shelter. Another subtle subtext that Ford presents us with, in a filmography where subtext is a hallmark. 


\section{Conclusion}

The strong presence of Aristoteles' drama elements in "The Searchers"' narrative comes as no surprise, as Hollywood's narrative techniques strongly rely on Aristoteles' "Poetica". From the standard three act structure to character construction, plot organization and conflict creation, Hollywood created an entire system of narrative construction and screenplay writing, departing from Aristoteles and perfecting it continuously until today, always searching for the perfect way to keep the viewers hooked on the screen. Being a long-time Hollywood director and producer, Ford worked within the system and it is no wonder that his film culture and practice fits perfectly within the Hollywood canon. It was therefore absolutely fit to resort to Aristoteles to bring some light into this Ford's film, a film from a Hollywood insider who, in spite of that, always maintain a critical eye on his work and a fresh angle on his usual themes.

\section{Final Notes}

\footnotetext{
1 "The Man who Shot Liberty Valance" is about the civilization of the west, a dear thematic to Ford.

${ }^{2}$ Some authors, like Robert McKee, Christopher Vogler, or even Melanie Phillips and Chris Huntley have different propositions for structure. But their proposals are mostly variations on Aristoteles proposal, altering or adding on that.
}

\section{Bibliography}

Anderson, Lindsay. 1981. About John Ford, London, Plexus

Aristóteles. 2008. Poética. Translation and notes by Ana Maria Valente, preface by Maria Helena da Rocha Pereira. ( $3^{a}$ Edition). Lisboa: Edição Fundação Calouste Gulbenkian. ISBN 978-972-31-1077-7

Baxter, John. 1971. The cinema of John Ford. London:

A. Zwemmer.

Bazin, André. 1992. O que é o Cinema?, Lisboa: Livros Horizonte. ISBN 972-24-0826-7

Bronfeld, S. 1986. Writing for film and television. New York: Simon \& Schuster. ISBN: 0-671-62828-3 Pbk

Cano, P.L. 1998. "Las fuentes clásicas del guión.” In L. Vilches (Org.), Taller de Escritura para Cine, (pp. 73-99). Barcelona: Gedisa Editorial.

Clascà, M. (1999). "Elementos Técnicos para la Escritura de Guión." In L. Vilches (Org.), Taller de Escritura para Televisión, (pp. 125-148). Barcelona: Gedisa Editorial.

Field, S. 1984. Screenplay: The foundations of screenwriting. New York: Dell Publishing. ISBN: 0-44057647-4

Gallagher, Tag, John Ford, the man and his films, University of California Press, Berkeley, 1986 https:// books.google.pt/books?hl=pt-PT\&lr=\&id=BaBUDwAA QBAJ\&oi=fnd\&pg=PP7\&dq=john+ford+director\&ots=M 4Ts4Yuxaw\&sig=7FiRqe41 vrYHp2t16lc8OwDfxzl\&red ir_esc $=\mathrm{y} \# \mathrm{v}=$ onepage $\& \mathrm{q}=\mathrm{john} \% 20$ ford $\% 20$ director $\& \mathrm{f}=$ false (acedido a 14/03/2019)

Graf, Peter A. 2013. Indian Identity: Case studies of three John Ford narrative western films. The Pennsylvania State University. https://etda.libraries.psu.edu/files/final_ submissions $/ 8315$
Henderson, Brian. 1985. "The Searchers: An American Dilemma." In Movies and Methods, vol. II, edited by Bill Nichols, (pp. 429-449). 1985. Berkeley, Los Angeles, London: University of California Press. ISBN 0-520-05409$1 \mathrm{Pbk}$

Mckee, R. 1997. Story: Substance, structure, style, and the principles of screenwriting. (1 $1^{\text {st }}$ edition). New York: Regan Books. ISBN 0-06-039168-5. Acedido a 21/04/2020 em: https://www.academia.edu/34390085/ Robert_McKee_-_Story_pdf

Phillips, M. \& Huntley, C. (2009). Dramatica - A New Theory of Story. (10 ${ }^{\text {th }}$ Aniversary Edition). Write Brothers Press. ISBN 0-918973-04-X

Place, Ann Jane. 1974. The western films of John Ford, Seacaucus, Citadel.

Seger, L. (1994). Cómo convertir un buen guión en un guión excelente. ( $4^{\mathrm{a}}$ edición). Madrid: Ediciones Rialp. Acedido a 21/04/2020 em: https://www.academia. edu/11365481/Linda_Seger-_C\%C3\%B3mo_convertir un_buen_gui\%C3\%B3̄n_en_un_gui\%C3\%B3n_excelente

Studlar, G e M Bernstein. 2001. John Ford made westerns: filming the legend in the sound era. http:// amwest.pbworks.com/w/file/fetch/56616490/Dagle $\% 20$ Linear\%20Patterns.pdf acedido a 14/03/2019 